\title{
The course of Echinococcus multilocularis infection and pregnancy in mice model
}

\author{
D. ANTOLOVÁ, K. REITEROVÁ \\ Institute of Parasitology of the Slovak Academy of Sciences, Hlinkova 3, 04001 Košice, Slovak Republic, \\ E-mail: antolova@saske.sk
}

\begin{abstract}
Summary
Parasitic infection during pregnancy can affect the course of pregnancy, complicate the foeto-maternal relationship and increase abortion rate. The work was aimed to study the course of E. multilocularis secondary infection and reproductive parameters in infected mice. The Balb/c mice were bred in the exponential phase of the metacestode growth, after infection with two different doses $(0.5 \mathrm{ml}$ or $1.25 \mathrm{ml}$ ) of metacestode material. In comparison to uninfected control group, the effect of infection on reproductive parameters (natality, size of litters) and the course of disease during pregnancy and after the delivery were monitored. The weight of E. multilocularis larval stages was higher in both fertilised groups in comparison to unfertilised control. The number of deliveries and litter counts were similar in both, infected and uninfected mice. Present study confirmed only minor impact of alveolar echinococcosis on the reproduction of rodents, intermediate hosts of parasite.
\end{abstract}

Keywords: Echinococcus multilocularis; infection; reproduction; mice

\section{Introduction}

Echinococcus multilocularis, causative agent of alveolar echinococcosis, serious helminthozoonosis, is small tapeworm with extensive geographic distribution in the Northern Hemisphere. The untreated disease is lethal in $94-$ $100 \%$ of human patients (Ammann \& Eckert, 1996). Life cycle is predominantly sylvatic, with carnivores, primarily red foxes, as definitive hosts and mammals, especially rodents, as intermediate hosts. In endemic areas, other wild and domestic carnivores, such as wolfs, racoon dogs, dogs and cats (Petavy et al., 2000; Deplazes \& Eckert, 2001; Antolová et al., 2009) can be involved as definitive hosts. Formation of semi-synanthropic or synanthropic life cycle is enhanced by spread of red foxes into urban and periurban zones, phenomenon observed in many European cities (Gloor et al., 2001).

In Slovakia, E. multilocularis was for the first time detected in 1999 (Dubinský et al., 1999). Recent study in red foxes (Vulpes vulpes) have shown $31.1 \%$ overall prevalence of parasite, with the highest prevalence in the northern parts of the country. In some districts an estimated prevalence overreached $60 \%$ (Miterpáková et al., 2009). Regional differences and between-year fluctuation of $E$. multilocularis prevalence in red foxes may be influenced by many circumstances. Besides climatic changes and other ecological factors, population density of intermediate hosts of this cestode seems to be the most important factor. Within the survey conducted between 2000 and 2004, Miterpáková et al. (2006a) observed close correlation between E. multilocularis prevalence in red foxes and abundance of small mammals.

In intermediate hosts, low prevalence of alveolar echinococcosis is usually found. Eckert (1997) states low infection rate of E. multilocularis metacestode, ranging between $<1 \%$ and $7 \%$, in Central Europe. Steiger et al. (2002) found $9.1 \%$ of Arvicola terrestris and $2.4 \%$ of Clethrionomys (Myodes) glareolus to be positive in Switzerland. In the Czech Republic, only one out of 229 (Martínek, et al., 1998) and in the Slovak Republic one out of 452 captured small mammals (Miterpáková et al., 2006b) was found to be infected with E. multilocularis. On the contrary, Hofer et al. (2000) observed $9 \%$ and $20 \%$ prevalence during two surveys in the city of Zürich and Gottstein et al. (1996) found local hot spot with infection rates in Arvicola terrestris of up to $39 \%$ in Canton of Fribourg in Switzerland. Mentioned findings correlate with the opinion of Gottstein et al. (1996) who assumed that $E$. multilocularis may occur in wild-living intermediate hosts in the form of local hyperendemicity.

Alveolar echinococcosis significantly influences health state of man, intermediate host of E. multilocularis 
(Kinčeková et al., 2005; Yang et al., 2005). In the Slovak Republic, women are infected more often than men, and although older patients dominate, women in fertile age are also affected (Kinčeková et al., 2008). Therefore, the question of influence of alveolar echinococcosis on pregnancy is of great impact.

An infection of any etiology can impair the course of gravidity, affect the foetus and consequently cause the abortion (Pavlinová et al., 2011). Despite of well researched E. multilocularis infection, there is a lack of knowledge about the impact of parasitic infection on pregnancy, therefore the work was aimed to study the course of E. multilocularis secondary infection in pregnant mice and, on the other hand, the influence of infection on reproductive parameters of mice.

\section{Material and methods}

\section{Biological material}

E. multilocularis metacestode (T1/85 strain, kindly provided by prof. Dr. H. Auer, Clinical Institute of Hygiene and Medical Microbiology, Medical University of Vienna, Austria) was maintained at the Institute of Parasitology SAS by intraperitoneal passage through Mongolian gerbils (Meriones unguiculatus). Metacetode material was isolated from intraperitoneally infected mice 4 months post infection (p.i.). Metacetode tissues were minced with scissors in sterile PBS supplemented with antibiotics $(100 \mathrm{U} / \mathrm{ml}$ penicillin and $100 \mu \mathrm{g} / \mathrm{ml}$ streptomycin [Sigma-Aldrich, Germany]) and passed through sterile sieve into the sterile Petri dish containing $5 \mathrm{ml}$ of PBS. Then, the solution with metacestode material was put into a sterile tube and after 5 minutes of sedimentation the sediment was intraperitoneally inoculated to experimental mice.

\section{Experimental design}

The experiment was carried out on inbred females Balb/c mice $(\mathrm{n}=280), 2$ months old, weighing $25-30 \mathrm{~g}$. Mice were kept under a $12 \mathrm{~h} \mathrm{light/dark}$ regime at room temperature $\left(21 \pm 3{ }^{\circ} \mathrm{C}\right)$ and $50-60 \%$ humidity on commercial diet and water. Experiments were performed in accordance with national guidelines of the Slovak Republic and ex- perimental protocol was approved by the Institute of Parasitology Animal Care Committee. Animals were randomly divided into 5 groups (60 animals per Group $1-4,40$ mice per Group 5). To compare the effect of different infection doses, two groups (1 and 2) were infected intraperitoneally with $0.5 \mathrm{ml}$ of homogenised metacestode material and two groups (3 and 4) with $1.25 \mathrm{ml}$ of the same metacestode material, respectively. Mice in Groups 1 and 3 were fertilised on day 60 post infection (p.i.), while Groups 2 and 4 remained unfertilised. Group 5 (control group) was uninfected and fertilised on the same day as mice in Groups 1 and 3.

In infected and uninfected animals, the number of deliveries and the number of offspring were recorded. To control the effect of fertilisation in animals examined before the delivery, the number of foetuses was counted during postmortem examination and sampling of cysts.

The weight of metacestode tissues was monitored in both fertilised and unfertilised mice on following days post infection (dpi): 28, 42, 56, 63, 70, 77, 84, 98, 112, 126, 140 and 170 ( 5 mice per sampling day).

\section{Statistical evaluation}

Statistical differences were assessed using One Way ANOVA, followed by post hoc Tukey's test ( $P$ level indicated in text), which allowed comparison between experimental groups. Chi-square test was used to evaluate the differences in the number of mice that did not give birth. The analyses were performed using the Statistica 6.0 (Stat Soft, Tulsa, USA).

\section{Results}

Effect of pregnancy and delivery on metacestode growth Weight of larval stages in animals infected with higher infective dose was higher then in those infected with lower dose $(\mathrm{P}>0.05)$. The course of metacestode growth was similar in both, fertilised and unfertilised animals. After day 77 p.i. the metacestode in fertilised mice started to grow more intensively. Similar trend was observed until the end of experiment and the established differences were not of statistical significance (Fig. 1).

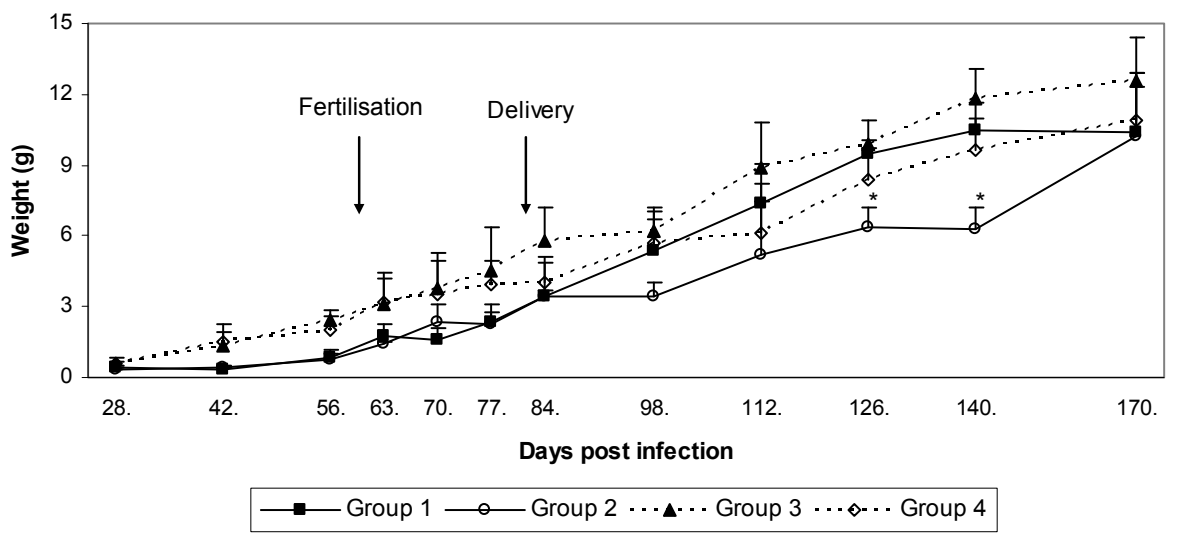

Fig. 1. Dynamics of metacestode weight in fertilised and unfertilised Balb/c mice infected with 0.5 or $1.25 \mathrm{ml}$ 
Influence of E. multilocularis infection on reproduction The number of deliveries in infected mice (Groups 1 and 3 ) and in Group 5 (uninfected control) was evaluated. Out of 45 animals examined during or after the pregnancy in Group 1 five $(11.1 \%)$ mice did not gave birth, $8(17.7 \%)$ animals from Group 3 and four $(10.0 \%)$ out of 40 uninfected mice (Group 5) did not deliver. The differences in the number of deliveries in infected and uninfected animals were not statistically significant $(\mathrm{P}>0.05)$.

The differences in the counts of litter were also non-significant $(\mathrm{P}>0.05)$; both, healthy and infected mothers produced on average $6-7$ offspring, ranging from 2 to 14 progenies per litter (Tab. 1).

In animals dissected in the course of pregnancy, no pathologic changes were observed on reproductive apparatus. represent key factors needful for existence of $E$. multilocularis hyperendemic localities. Hansen et al. (2004) observed the correlation between the occurrence of infected intermediate hosts and conditions optimal for eggs survival. The population density of small mammals in natural conditions is not equal and their home range often covers only few square meters. Red foxes visit localities with high population density of small mammals more frequently what results in accumulation of their faeces containing parasite eggs in such places (Antolová et al., 2004). This phenomenon leads to constant re-infection of foxes and, consequently, to more rodents being infected within the home-range of infected foxes. It is also possible that infected intermediate hosts are more exposed to predation because the growing metacestode destroys their liver tis-

Table 1. Offspring in Balb/c mice infected with different amount of metacestode material

\begin{tabular}{lccc}
\hline Experimental group & $\begin{array}{c}\text { Number of } \\
\text { offspring }\end{array}$ & $\begin{array}{c}\text { Min. and max. of } \\
\text { offspring/delivery }\end{array}$ & $\begin{array}{c}\text { Average No. of offspring /delivery } \\
\pm \text { SD }\end{array}$ \\
\hline Group 1 (0.5 ml) & 277 & $3-14$ & $6.92 \pm 2.44$ \\
Group 3 (1.25 ml) & 270 & $3-12$ & $7.30 \pm 2.42$ \\
Group 5 (uninfected) & 265 & $2-14$ & $7.35 \pm 2.91$ \\
\hline
\end{tabular}

\section{Discussion}

Parasitic infection during pregnancy represents a stress factor that can affect the course of pregnancy, complicate foeto-maternal relationship and cause the abortion (Reiterová et al., 2003). E. multilocularis induces generalized immunosuppression of the host organism (Dvorožňáková et al., 2008; 2009), what could influence the course of gravidity in infected mice. On the other hand, the immunological changes during pregnancy may affect the course of parasitic infection (Nuñez et al., 2002). Although infection caused severe damage of liver and the metacestode weight in some mice reached a third of their body weight, the most of infected animal completed their pregnancy successfully, delivering healthy litter. Similar phenomenon we observed also in Mongolian gerbils (unpublished data). In the study, higher infection dose caused abortions more frequently $(17.7 \%)$ than the lower one $(11.1 \%)$, but when comparing with uninfected fertilised mice (10\% abortions), we can conclude that the number of parturitions was influenced only to a small extend. The number of progenies was also similar in infected and uninfected mothers. Despite relatively small impact of infection on reproductive parameters, the course of the disease seems to be more serious in mice after the delivery, in which metacestode weight was higher than in unfertilised control. Similarly, in pregnant women with alveolar echinococcosis unusual increase of lesion size has been observed (Yang et al., 2005; Vuitton et al., 2006).

The prevalence of alveolar echinococcosis in intermediate hosts is determined by the character of locality in which the monitoring is conducted. The landscape pattern favourable for intermediate hosts, together with humid conditions and low temperatures that facilitate the survival of eggs, sue, reducing their mobility (Hansen et al., 2004).

In case of similar course of disease and pregnancy in outbred mice and wild rodents we can suppose that increased weight of metacestode tissues in pregnant animals reduces their mobility and facilitates their catch by predators, contributing to permanent reinfection of definitive host, especially in hyperendemic localities. Moreover, such localities pose higher risk of exposure to E. multilocularis infection for humans. Rodents can transmit infectious agent also to domestic carnivores, facilitating transmission of the disease to man (Hildebrand et al., 2009). Therefore, preventive measures, for example anthelmintic bait distribution that decreases E. multilocularis prevalence in definitive hosts (Antolová et al., 2006; Romig et al., 2007), should be applied to reduce infection pressure on men in hyperendemic areas.

\section{Acknowledgement}

The publication has been realized within a frame of the project Centre of Excellence for Parasitology (Code ITMS: 26220120022) based on the support of the Operational Programme "Research \& Development" funded from the European Regional Development Fund (rate 0.8) and partially financed by the Slovak Grant Agency VEGA, Grant No. $2 / 0145 / 09$.

\section{References}

Ammann, R. W., EcKert, J. (1996): Cestodes: Echinococcus. In: WeInstock, J. V. (Eds) Parasitic diseases of the liver and intestines. Philadelphia: W.B. Saunders Comp., pp. $655-689$

Antolová, D., Reiterová, K., MiterpákovÁ, M., 
Stanko, M., DubinskÝ, P. (2004): Circulation of Toxocara spp. in suburban and rural ecosystems in the Slovak Republic. Vet. Parasitol., 126: 317 - 324. DOI: 10.1016/ j.vetpar.2004.08.005

AntolovÁ, D., MiterpákovÁ, M., ReiterovÁ, K., DUBINSKÝ, P. (2006): Influence of anthelmintic baits on the occurrence of causative agents of helminthozoonoses in red foxes (Vulpes vulpes). Helminthologia, 43: 226 - 231. DOI: 10.2478/s11687-006-0042-9

Antolová, D., Reiterová, K., MiterpákovÁ, M., DinKel, A., DuBINSKÝ, P. (2009): First Finding of Echinococcus multilocularis in Dogs in Slovakia: an Emerging Risk for Spreading of Infection. Zoonoses and Public Health, 56: 53 - 58. DOI: 10.1111/j.1863-2378.20 08.01154.x

DePlAZES, P., ECKERT, J. (2001): Veterinary aspects of alveolar echinococcosis - a zoonosis of public health significance. Vet. Parasitol., 98: 65 - 87

DUBINSKÝ, P., SVOBODOVÁ, V., TURČEKOVÁ, L', LITERÁK, I., MARtíneK, K., ReITEROVÁ, K., KolÁŘOVÁ L., KLIMEŠ, J., MrLÍK, V. (1999): Echinococcus multilocularis in Slovak Republic: The first record in red foxes (Vulpes vulpes). Helminthologia, 36: $105-110$

DVOROŽNÁKOVÁ, E., PORUBCOVÁ, J., ŠNÁBEL, V., FEDOROČKO, P. (2008): Immunomodulative effect of liposomized muramyltripeptide phosphatidylethanolamine (L-MTP-PE) on mice with alveolar echinococcosis and treated with albendazole. Parasitol. Res., 103: 919-929. DOI: $10.1007 / \mathrm{s} 00436-008-1077-2$

DVOrožŇÁKovÁ, E., PorUBCOVÁ, J., ŠEvČíkOVÁ, Z. (2009): Immune response of mice with alveolar echinococcosis to therapy with transfer factor, alone and in combination with albendazole. Parasitol. Res. 105: 10671076. DOI: 10.1007/s00436-009-1520-z

ECKERT, J. (1997): Epidemiology of Echinococcus multilocularis and E. granulosus in Central Europe. Parassitologia, 39: 337 - 344

Gloor, S., Bontadina, F., Hegglin, D., Deplazes, P., BREITENMOSER, U. (2001): The rise of urban fox population in Switzerland. Mamm. Biol., 66: 155 - 164

Gottstein, B., Saucy, F., Wyss, C., Siegenthaler, M., JACQuier, P., Schmitt, M., Brossard, M., Demierre, G. (1996): Investigations on a Swiss area highly endemic for Echinococcus multilocularis. Appl. Parasitol., 37: 129 - 136 Hansen, F., Jeltsch, F., Tackmann, K., Staubach, C., THulKe, H. H. (2004): Processes leading to a spatial aggregation of Echinococcus multilocularis in its natural intermediate host Microtus arvalis. Int. J. Parasitol., 34: 37 - 44. DOI: 10.1016/j.ijpara.2003.10.003

Hildebrand, J., Zalesny, G., OKulewicz, A., BASZKIEWICZ, K. (2009): Preliminary studies on the zoonotic importance of rodents as a reservoir of toxocariasis from recreation grounds in Wroclaw (Poland). Helminthologia, 46: 80 - 84. DOI: 10.2478/s11687-0090016-9

Hofer, S., Gloor, S., Müller, U., Mathis, A., Hegglin, D., DePlazes, P. (2000): High prevalence of Echinococcus multilocularis in urban red foxes (Vulpes vulpes) and voles
(Arvicola terrestris) in the city of Zürich, Switzerland. Parasitology, 120: 135 - 142

KinČEKOVÁ J., DUBINSKÝ, P. JR., DVOROŽŇÁKOVÁ, E., Auer, H., HudaČKOVÁ, J., DAŇOVÁ, M., StanislayovÁ, M., Straka, L., SzILÁGYOVÁ, M. (2005): Diagnostics and occurrence of alveolar echinococcosis in Slovakia. Czech Slov. Gastroenterol. Hepatol., 59: 11 - 16 (in Slovak)

KINČEKOVÁ, J., PAVlinOVÁ, J., DUBINSKÝ, P. JR., VRZGULA, A., ZACHAR, M. (2008): Occurrence of echinococcosis and its clinical symptoms in humans - current status in Slovakia. Slov. Vet. čas., 33: 102 - 104 (In Slovak)

MartíneK, K., KolÁŘovÁ, L., ČErvenÝ, J., ANDreas, M. (1998): Echinococcus multilocularis (Cestoda: Taenidae) in the Czech Republic: the first detection of metacestodes in a naturally infected rodent. Folia Parasitol., 45: 332 - 333

MiterpákOVÁ, M., DubinskÝ, P., ReITERovÁ, K., StAnKo, M. (2006a): Climate and environmental factors influencing Echinococcus multilocularis occurrence in the Slovak Republic. Ann. Agr. Env. Med., 13: 235 - 242

MiterpákOVÁ, M., ANTOlovÁ, D., ŠEVČíKOVÁ, Z., Stanko, M., Dinkel, A., GaŠPar, V., DubinskÝ, P. (2006b): Echinococcus multilocularis in musk rat (Ondatra zibethicus): the first finding of the parasite in naturally infected rodent in the Slovak Republic. Helminthologia, 43: $76-80$

MiterpákovÁ, M., HurníkovÁ, Z., Antolová, D., DUBINSKÝ, P. (2009): Endoparasites of red fox (Vulpes vulpes) in the Slovak Republic with the emphasis on zoonotic species Echinococcus multilocularis and Trichinella spp. Helminthologia, 46: 73 - 79. DOI: 10.24 78/s11687-009-0015-X

Nuñez, G. G., Gentile, T., Calgano, M. L., VENTURIELlO, S. M. (2002): Increased parasiticide activity against Trichinella spiralis newborn larvae during pregnancy. Parasitol. Res., 88: 661 - 667. DOI: 10.1007/ s00436-002-0599-2

Pavlinová, J., KinčeKová, J., Ostró, A., SAKsun, L., VAsILKOVÁ, Z., KÖNIGOVÁ, A. (2011): Parasitic infections and pregnancy complications. Helminthologia, 48: 8- 12 . DOI: 10.2478/s11687-011-0002-X

Petavy, A. F., Tenora, F., Deblock, S., Sergent, V. (2000): Echinococcus multilocularis in domestic cats in France. A potential risk factor for alveolar hydatid disease contamination in humans. Vet. Parasitol., 87: $151-156$ ReiterovÁ, K., TOMAŠOVIČOVÁ, O., DuBINSKÝ, P. (2003): Influence of maternal infection on offspring immune response in murine larval toxocariasis. Parasite Immunol., 25: $361-368$

Romig, T., Bilger, B., Dinkel, A., Merli, M., Thoma, D., Will, R., Mackenstedt, U., Lucius, R. (2007): Impact of praziquantel baiting on intestinal helminths of foxes in southwestern Germany. Helminthologia, 44: 137144. DOI: $10.247 / \mathrm{s} 11687 / 007-0021-9$

Steiger, C., Hegglin, D., Schwarzenbach, G., Mathis, A., DePlazes, P. (2002): Spatial and temporal aspects of urban transmission of Echinococcus multilocularis. Parasitology, 124: 631 - 640. DOI: 10.1017/S00311820 02001749 
Vuitton, D. A., Zhang, S. L., YAng, Y., Godot, V., Beurton, I., Mantion, G., Bresson-Hadni, S. (2006): Survival strategies of Echinococcus multilocularis in the human host. Parasitol. Int., 55: S51 - S55. DOI: 10.1016/j.parint.2005.11.007

RECEIVED MARCH 14, 2011
Yang, Y. R., Vuitton, D. A., Jones, M. K., Craig, P. S., MCMANUS, D. P. (2005): Brain metastasis of alveolar echinococcosis in hyperendemic focus of Echinococcus multilocularis infection. T. Roy. Soc. Trop. Med. H., 99: $937-941$

ACCEPTED August 27, 2011 